\title{
Digitalisering af færdighedstræning og laboratorieøvelser
}

\section{Peter K. Fridorff-Jens}

E-læringskonsulent

Center for Online og Blended learning, KU

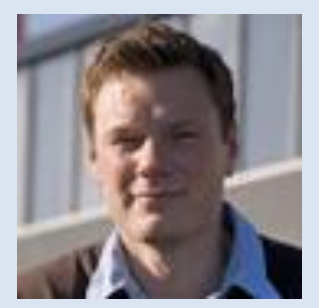

\section{Cita Nørgaard}

Pædagogisk konsulent

SDU Universitetspædagogik, SDU

\section{Mads Ronald Dahl}

$\mathrm{PhD}, \mathrm{MI}$

Center for Medicinsk Uddannelse, AU
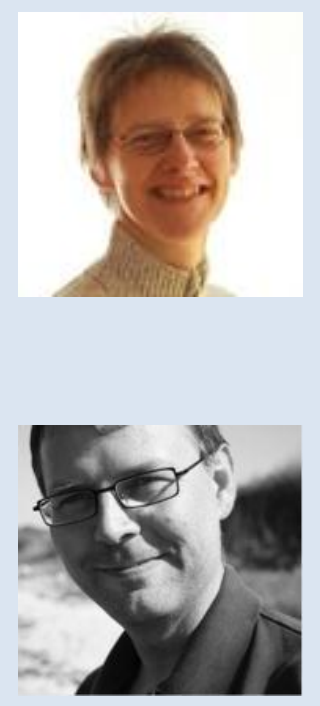


\section{Introduktion}

Dette temanummer af "Læring og Medier" sætter fokus på digitalisering af færdighedstræning og laboratorieøvelser på universiteter og UC’er.

Der er mange krav og hensyn, som skal tilgodeses, når vi digitaliserer, og det har altid indflydelse på arbejdsgange, kommunikation og læringen. Helt overordnet bliver der stillet nye krav til uddannelsesinstitutionerne fra samfundet i form at f.eks. pejlemærker:

\section{"I undervisningen skal der skabes rum for innovation og kreativitet. Universiteterne skal derfor styrke indsatsen for at bruge it til at understøtte undervisning og anden læring."}

\section{Den digitale vej til fremtidens velfærd, Den fællesoffentlige digitaliseringsstrategi 2011-2015, Regeringen/KL/Danske Regioner, august 2011}

Den teknologiske udvikling har eskaleret mængden af digitaliserede træningstilbud, der i højere grad indgår som en naturlig del af undervisningen på flere uddannelsesområder. Af eksempler kan nævnes simulerede rollespil, virtuel case undervisning, sproglig færdighedstræning, simulatorer og digitale laboratorier.

I dette temanummer lægges der op til, at dele erfaringer og best practice man har gjort sig med digitalisering af færdighedstræning og anden inddragelse af medier i simulations- og laboratorieområder på det naturog sundhedsvidenskabelige felt samt på de tekniske videnskaber.

Et argument for implementering af nye medier som læringsredskab i uddannelserne kan være et ønske om effektivisering af den undervisning som tilbydes. Det øgede optag af studerende og kursister samt krav om modernisering, medfører et behov for nytænkning af undervisningsformer såsom digitale laboratorieøvelser, færdigheds- og simulationstræning.

Ved at få fortalt om de seneste tiltag som organisationerne, centrene og ildsjælene arbejder med, kan der drages nytte af erfaringerne på tværs af institutionerne.

Digitalisering af færdighedstræning og laboratorieøvelser har en mangfoldighed og kompleksitet, som gør det relevant at sætte fokus på det med et temanummer. Undervisningsforløb hvor færdighedstræning eller laboratorieøvelser indgår kan anskues fra mange vinkler med fokus på lige fra forberedende administrative opgaver, til IKT udfordringer eller datasikkerhed. Den praktiske undervisning i "håndværket" har mange facetter, hvilket afspejler sig i den forskelligartethed samlingen af artikler i LOM \#12 viser. 
Dette temanummer indeholder et antal artikler, der spreder sig over politiske, organisatoriske, tekniske og pædagogiske aspekter ved digitalisering af færdighedstræning og laboratorieøvelser i undervisningen på universiteter og UC'er. Artiklerne rummer cases og erfaringer med teknologierne samt teoretiske refleksioner og undersøgelser af effekten. Artiklerne vidner om en varieret brug af interaktive medier $\mathrm{i}$ undervisningen. Især video indgår som et bærende element og omdrejningspunkt i mange af artiklerne, En trend vi har set de sidste mange år inden for området

De artikler som er blevet skrevet til dette nummer af LOM har vi valgt at inddele i tre temaer og en reportage.

\section{Tema 1 - Studenterorienteret færdighedstræning}

Opsætning af didaktisk design og tekniske faciliteter ud fra pædagogiske principper, der stimulerer motivation, studenterinddragelse og aktiverende læringsprocesser. Samtidig befordres praksisnær tilknytning og læring optimeres. Det er i den sammenhæng en diskussion hvordan det evt. koordineres med eller bevæges ud fra en mere traditionel undervisningsform i færdighedstræning - ofte mesterlæreprincipper. "Studierummet" arbejdes væk fra det lærerorienterede til det studenterorienterede "studierum".

Begge de følgende artikler bruger videomediet i træning af færdigheder både gennem instruktionelle videopodcasts og igennem stundenterfremstillede videopodcasts. Feedback på studerendes arbejder og refleksioner over egen udførelse af færdigheder er gennemgående temaer (Nørgård et al.) og (Nielsen og Eriksen).

Et andet eksempel på færdighedstræning, hvor feedback spiller en markant rolle findes hos Rosthøj. Her arbejdes med feedback i online e-tests i statistikundervisning. En form for "Flipped Classroom" tilgang. Alle eksempler i dette tema om studentenorienteret færdighedstræning kan siges at bringe inspiration til tænkningen omkring flipped classroom i situationer med færdighedstræning.

\section{Tema 2 - Formative og summative bedømmelsesformer indenfor færdighedstræning}

På sundhedsvidenskabelige uddannelser er færdighedstræning gennem praktik- og klinikforløb en vigtig del af uddannelserne. Dokumentation af læringsforløb med brug af velintegrerede digitale medier kan styrke muligheden for en formativ evaluering og mediere en kontinuerlig feedback fra underviser til studerende og mellem de studerende. 
I artiklen (Hansen JS et al,) beskrives de studerende og undervisernes erfaringer med brug af online dagbogen til et praktikforløb og til kommunikationstræning. Et af de spændende identificerede fund er online dagbogens styrke netop der hvor underviseren har mulighed for at bryde ind undervejs i refleksionsspiralen og påvirke den studerendes videre refleksion og praktikforløb med feed back.

Den summative digitale evaluering af OSKE eksamen for medicinstuderende bliver beskrevet i artiklen af Krogh K et al. De politiske udmeldinger bliver taget bogstaveligt og alle analoge arbejdsgange i forbindelse med afviklingen af den omfattende færdighedseksamen

\section{Tema 3 - Træning af kliniske færdigheder under klinikophold}

Omdrejningspunktet i tema tre er det kliniske ophold for medicinstuderende. Artiklerne beskriver på hver deres måde hvordan træningen af konkrete færdigheder kan ske. Artiklerne spænder over erfaringer med træning af praktiske færdigheder via apps til brugen af workshops med simulerede patientvideocases til kommunikationsundervisning inden for psykiatrien hvor man bruger Ipadden som støtteredskab til læring. Undervisningsperspektiverne er ofte i disse scenarier "just in time learning" og "on demand learning" . Der er i dette tema et læringsmæssigt overlap med tænkningen i tema 1 dels via flipped classroom, en nytænkning over mesterlæreprincippet samt brugen af feedback og selvrefleksion.

I artiklen af Fog Petersen beskrives erfaringer og resultater af inddragelse af iPads som videoredskab og støtteredskab til læring og supervision under medicinstuderendes klinikophold i psykiatri.

Erfaringer og resultater med udvikling af en web-app med videoer af kliniske ledundersøgelser diskuteres i artiklen af Subhi et al. ,samt betydningen af brugsmønsteret og brugen af smartphones blandt medicinstuderende på deres kliniske ophold.

I den sidste artikel af Balslev og Leegaard beskrives hvordan man ved brug af workshops med autentiske patientvideocases kan skabe grobund for dannelsen af kognitive mønstre kaldet illness scripts, hos medicinstuderende i deres klinikophold.

\section{Reportage fra et innovativt undervisningsmiljø}

Digitalisering af undervisningen i almen patologi fokuserer på digitaliseringsinitiativer som rammer de medier de studerende i forvejen anvender. Der arbejdes med at finde det holdbare design for at understøtte de studerendes læring i det aktuelle indhold og forståelse for tolkning af patologiske vævsprøver og snit. 
Samlingen af artikler i dette temanummer af LOM illustrerer, at der rundt om i organisationer er mange forskellige interessante initiativer i gang, $\mathrm{i}$ forhold til at se på, hvordan undervisning og læring bl.a. teknologisk kan understøttes og være medvirkende til at skabe nye, spændende og alternative undervisningsmiljøer og metoder.

God fornøjelse med den videre læsning af artiklerne mange hilsner

Redaktørerne 